\title{
Yield and yield components of tomato grafted plants in the high Andean region of Colombia
}

\author{
Rendimiento y componentes del rendimiento en plantas \\ injertadas de tomate en la región alto Andina en Colombia
}
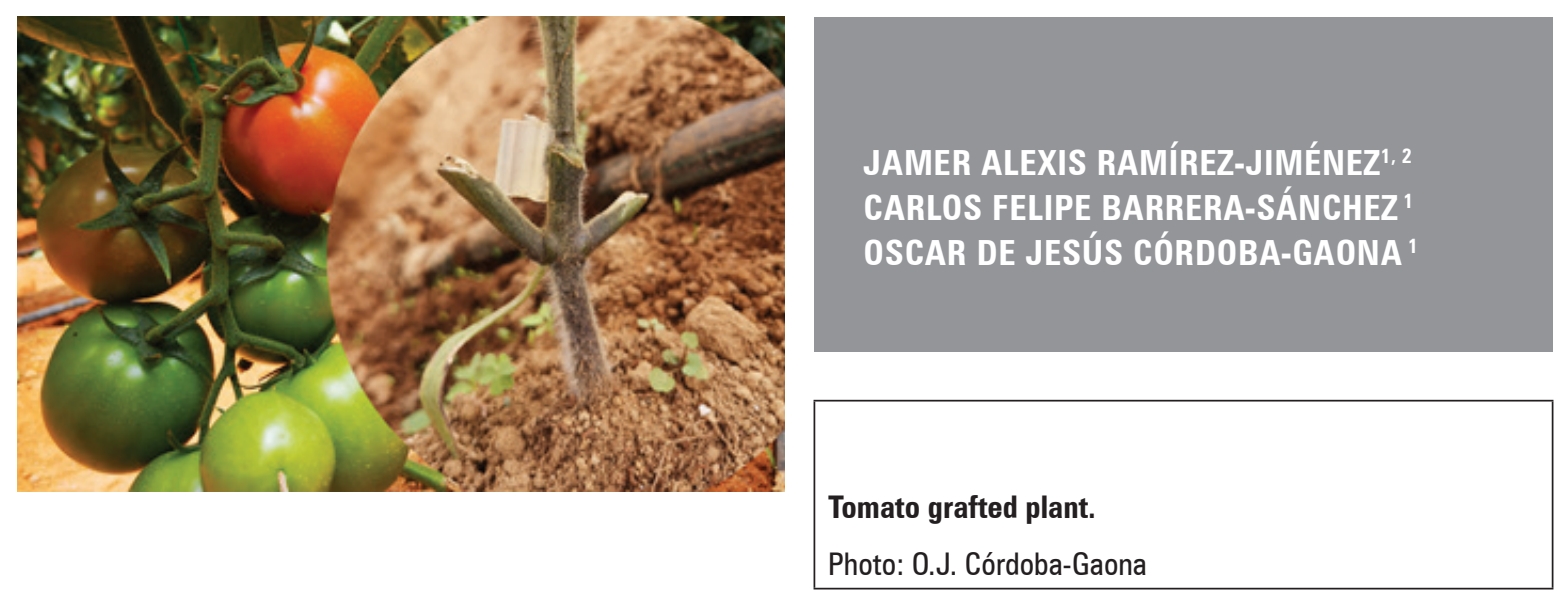

\section{ABSTRACT}

Grafting as a technique is gaining attention, and the production and demand for grafted vegetable plants have increased worldwide, especially for greenhouse cultivation. This study aimed to evaluate the potential of different scion $\times$ rootstock combinations or improving the yield of the tomato crop under greenhouse conditions. For this purpose, a scion of tomato cv. Libertador was grafted on two commercial tomato rootstock ('Olimpo' and 'Armada') and cultivated in a greenhouse in a randomized complete block experiment design, with four scion-rootstock combinations: vigor and resistance rootstocks, self-grafting and non-grafted plants. The yield and yield components were evaluated (number and weight of the fruits of extra, commercial, and non-commercial quality, weight per cluster, and weight per fruit). Although vigor rootstocks produce less fresh fruit in the first harvests, from the seventh harvest onwards, the vigor rootstocks outperformed the other treatments in the accumulated yield by producing 37, 22 and $22 \%$ more yield, and 60,30 and $40 \%$ higher number of fruits of extra quality in the resistance rootstock, self-grafted, and non-grafted plants. The fruits plants of vigor rootstock, selfgrafted and non-grafted above $150 \mathrm{~g}$, tend to have a cylindrical shape; however, fruits in the resistance rootstock tend to be flattened. The use of a vigor rootstock increased the yield of cv. Libertador, regarding the rootstock with resistance characteristics and controls, self-grafted, and non-grafted plants.

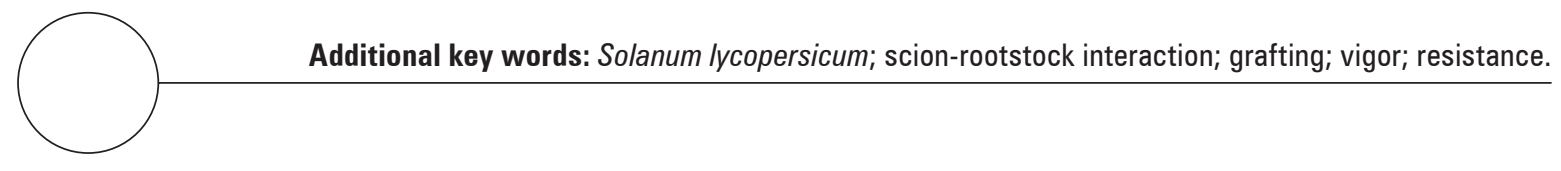

Universidad Nacional de Colombia, Facultad de Ciencias Agrarias, Medellin (Colombia). ORCID Ramírez-Jiménez, J.A.: 0000-0001-7768-1631; ORCID Barrera-Sánchez, C. F.: 0000-0002-5015-2956; ORCID Córdoba-Gaona, O.J.: 0000-0003-2642-4146

2 Corresponding author. jaaramirezji@unal.edu.co 


\section{RESUMEN}

La injertación es una técnica que ha ido incrementando en todo el mundo, especialmente en el cultivo de tomate en invernadero. El objetivo de este trabajo fue evaluar los componentes de rendimiento y el rendimiento de un cultivar comercial de tomate injertado sobre diferentes combinaciones de patrones de la región altoandina de Colombia; para ello el cultivar Libertador fue injertado sobre los patrones 'Olimpo' y 'Armada', y como controles se utilizaron plantas auto injertadas y no injertadas del mismo cultivar. Se empleo un diseño de bloques al azar con cuatro repeticiones y cuatro tratamientos: patrón vigor ('Olimpo'), patrón resistencia ('Armada'), autoinjerto y no injertadas. Hubo diferencias significativas entre tratamientos para el rendimiento acumulado. Las plantas de tomate injertadas en el portainjerto vigor produjeron 37, 22 y $22 \%$ más de peso de fruto, y 60,30 y $40 \%$ más de frutos de calidad extra, en comparación con los tratamientos patrón de resistencia, plantas auto injertadas y no injertadas. Se observó que, si bien el uso de un patrón de vigor condujo a una menor producción de fruta en las primeras cosechas, a partir de la séptima cosecha, este tratamiento fue superior a los demás, en cuanto al rendimiento acumulado. Los frutos en el tratamiento vigor, auto injertos y plantas no injertadas que superaron los $150 \mathrm{~g}$ tienden a tener forma cilíndrica; mientras que, los frutos del tratamiento resistencia tienden a presentar una forma achatada. El uso de un portainjerto vigoroso aumentó el rendimiento del cv. Libertador, con respecto a los tratamientos portainjerto con características de resistencia y a los tratamientos control, plantas auto injertadas y no injertadas.

Palabras clave adicionales: Solanum lycopersicum; interacción portainjerto-patrón; injertación; vigor; resistencia.

Received for publication: 01-09-2020 Accepted for publication: 23-11-2020

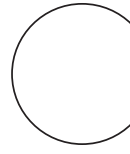

The tomato (Solanum lycopersicum L.) is one of the more important and popular vegetable crops in the world, which has generated a large number of studies focused on increasing the quality and yield of fruits and reducing the effects of different types of stress (Geboloğlu et al., 2011; Singh et al., 2017; Milenković et al., 2020). Tomato cultivation can be carried out in open fields and under protected conditions, where there are both biotic and abiotic limitations that affect growth, development, and fruit production (Djidonou et al., 2016; Singh et al., 2017). A strategy to respond to the demands of the private and public sector and overcome these types of limitations is grafting, a technique that is gaining full attention. The production of and demand for grafted vegetable plants have increased throughout the world, especially for greenhouse cultivation of vegetable crops (Geboloğlu et al., 2011; Reddy, 2016; Kumar and Sanket, 2017). The grafting process involves the union of two parts (a rootstock and scion) from two different plant parts to form a single living plant exhibiting the characteristics of both (Gaion et al., 2018; Sen et al., 2018). Initially, grafting was used widely in vegetable crops to limit the effects of soilborne pathogens; however, the utility of grafting has widened over the years. Grafted plants have been successfully used to induce tolerance against salinity (Singh et al., 2020), drought (Fullana-Pericàs et al., 2018), flooding (Bhatt et al., 2015), temperature stress (Muneer et al., 2016), and adverse chemical soil conditions (MartínezAndújar et al., 2017), among other purposes. The new and improved root system provides tolerance through grafting with deep and vigorous root formation (Aloni et al., 2010), improved soil water and nutrient uptake (Savvas et al., 2017), increased plant vigor and extended economic harvest time (Reddy, 2016; Kumar et al., 2017; Kumar and Sanket, 2017).

On the other hand, the effect of grafting on the yield of tomato plants is unclear, and some studies have confirmed that it increases (Pogonyi et al., 2005; Khah et al., 2006; Djidonou et al., 2016; Milenković et al., 2020); others have shown a performance equal to their controls and even unfavorable effects on yields with certain combinations (Miskovic et al., 2016; Milenković et al., 2020). In each production process, there are components that condition tomato yield; the consideration and quantification of these components estimate yield and facilitate decisions that guarantee higher production (Torres, 2017). In general, the differences in yield when tomato grafted plants are used are based on the increase in the size and quality of the fruits, without an increase in the number of fruits; likewise, it is related to the distribution of the 
harvest (Pogonyi et al., 2005; Khah et al., 2006; Djidonou et al., 2016; Milenković et al., 2020). Although grafting has become a useful tool for enhancing many traits in horticultural crops, its role in improving the tomato crop performance in the High-Andean region is not yet proven. The hypothesis was that the use of grafted plants improves tomato fruit yield, promoting the use of this technique for Colombian tomato producers. The objective of the present study was to evaluate the potential of different scion $\mathrm{x}$ rootstock combinations or improving the yield of tomato crops under greenhouse conditions.

\section{MATERIALS AND METHODS}

This experiment was carried out under greenhouse conditions on the El Socorro farm, El Santuario, Antioquia, Colombia (6 $6^{\prime} 55.8^{\prime \prime} \mathrm{N}$ and $75^{\circ} 13^{\prime} 10.15^{\prime \prime}$ $\mathrm{W}$, an elevation of $2.251 \mathrm{~m}$ ), which is in the highAndean region. Properties of the soil used in the experiment were sandy loam-clay-sandy texture, $\mathrm{pH}$ (5.0), EC (0.06 dS/m), OC (5.8\%), phosphorus (66 $\mathrm{mg} \mathrm{kg}^{-1}$ soil), sulfur (53.2 $\mathrm{mg} \mathrm{kg}^{-1}$ soil), Ca (10.6 $\mathrm{cmol}_{\mathrm{c}}$ $\left.\mathrm{kg}^{-1}\right), \mathrm{Mg}\left(3.0 \mathrm{cmol}_{\mathrm{c}} \mathrm{kg}^{-1}\right), \mathrm{K}\left(2.47 \mathrm{cmol}_{\mathrm{c}} \mathrm{kg}^{-1}\right)$, ECEC $\left(16.5 \mathrm{cmol}_{\mathrm{c}} \mathrm{kg}^{-1}\right), \mathrm{Fe}\left(74 \mathrm{mg} \mathrm{kg}^{-1}\right), \mathrm{Mn}\left(9 \mathrm{mg} \mathrm{kg}^{-1}\right), \mathrm{Cu}$ $\left(9 \mathrm{mg} \mathrm{kg}^{-1}\right), \mathrm{Zn}\left(5 \mathrm{mg} \mathrm{kg}^{-1}\right)$ and $\mathrm{B}\left(0.2 \mathrm{mg} \mathrm{kg}^{-1}\right)$. Based on the soil condition, tomato plant nutrition was applied using the chemical fertilization: $\mathrm{N}(35.3 \mathrm{~g}), \mathrm{P}_{2} \mathrm{O}_{5}$ (26 g), $\mathrm{K}_{2} \mathrm{O}$ (57.3 g), $\mathrm{MgO}$ (22.3 g), $\mathrm{CaO}$ (33 g), $\mathrm{S}$ (14 g), B (0.4), Cu (0.03 g), Fe (0.04 g), Mn (0.01 g), Mo $(0.001 \mathrm{~g}), \mathrm{Zn}(0.65 \mathrm{~g})$, and Si $(15 \mathrm{~g})$ per plant, applied through fertigation and distributed at planting and 45,80 , and $100 \mathrm{~d}$ after planting.

The average air temperature was $19.8^{\circ} \mathrm{C}$, and the absolute minimum and maximum temperatures were 10.1 and $43.4^{\circ} \mathrm{C}$; on the other hand, the average relative humidity was $77 \%$, with a maximum and minimum of 89 and $65 \%$. The maximum air temperature was above the maximum threshold $\left(35^{\circ} \mathrm{C}\right)$ in the middle of the days of the experiment period, while the minimum temperature was always above the base temperature for the tomato crop $\left(10^{\circ} \mathrm{C}\right)$ (Fig. 1). The volume of water and frequency of tomato irrigation are shown in figure 2. The irrigation of the crop was carried out with drip irrigation, applying a total volume per plant of $243.2 \mathrm{~L}$, and the average daily amount of water per plant was $1.42 \mathrm{~L}$.

A randomized complete block experiment design was used, with four (4) treatments and four (4) repetitions. The treatments consisted of a single commercial tomato scion grafted on different rootstocks combination: vigor rootstock, resistance rootstock, self-grafting, and non-grafted plants. Each experiment plot consisted of 32 tomato plants, spread over four rows of eight plants each, for an area of $15.84 \mathrm{~m}^{2}$.

The genotype (S. lycopersicum L.) used as a scion was a tomato Chonto cultivar Libertador, and the rootstock was two commercial materials: 'Olimpo' as vigorous rootstock and 'Armada' as disease resistant rootstock. The grafting methods were the tongue approach grafting, as described Lee et al. (2010) that

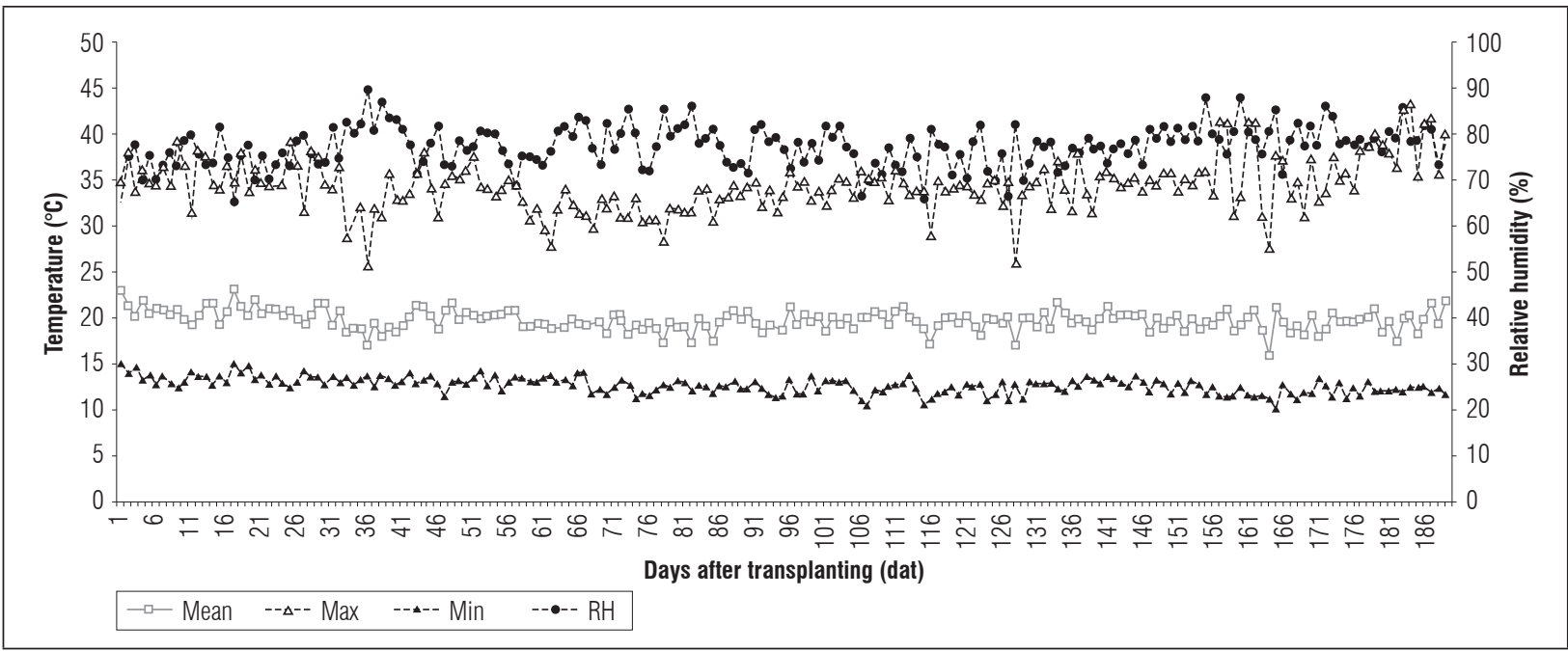

Figure 1. Daily mean temperature (Mean), maximum (Max), minimum (Min), and relative humidity (RH) in greenhouse between $04 / 23 / 2019$ to $10 / 25 / 2019$. 


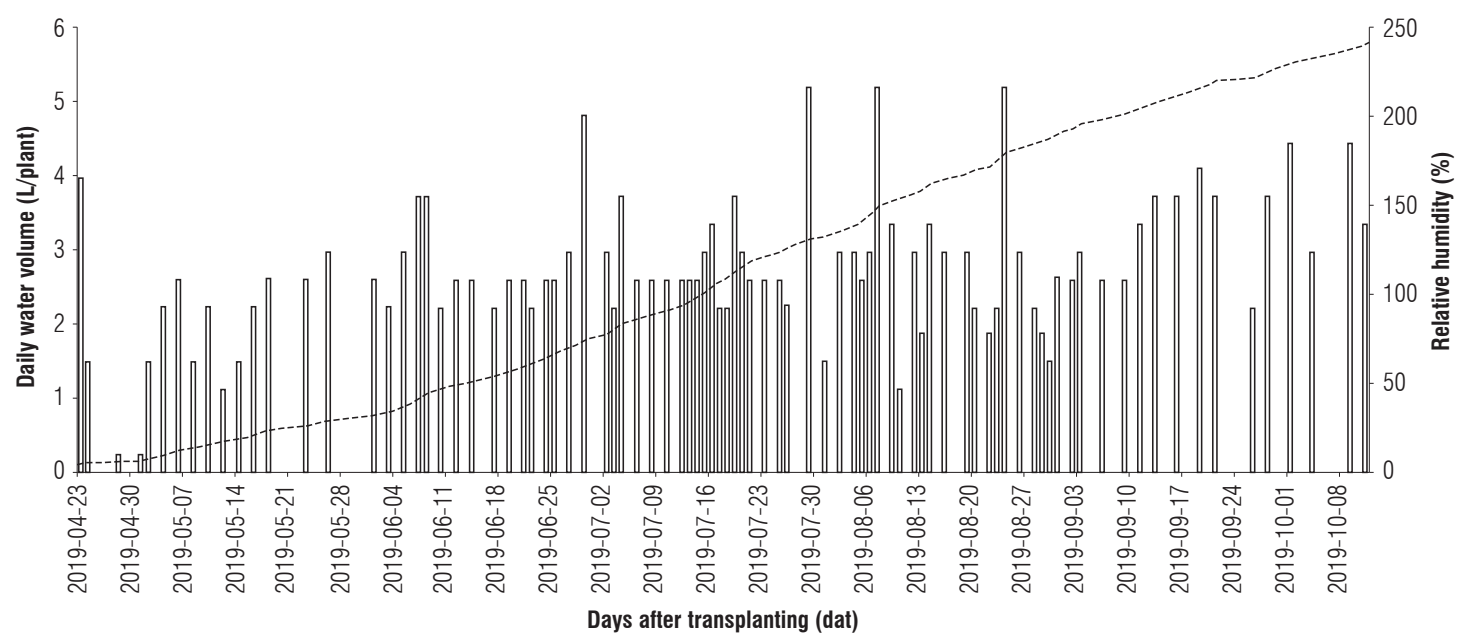

Figure 2. Frequency of drip irrigation, and daily volume and accumulated volume of water applied by tomato plant between $04 / 23 / 2019$ to $10 / 11 / 2019$.

consists in removing the growing point of the rootstocks and cutting the rootstock in a downward direction and the scion cut in an upward direction at an angle perpendicular axis, deep enough to allow the fusion of tongue insertion. After the graft is completed, specially designed clips are placed to fix the graft position. The non-grafted and grafted plants were transplanted to the greenhouse on April 29, 2019, each with the third leaf on the main shoot folded, corresponding to stage 103 on the $\mathrm{BBCH}$ scale proposed by Feller et al. (1997). The field planting distance was $1.1 \mathrm{~m}$ between rows and $0.45 \mathrm{~m}$ between plants, and the management allowed the first lateral shoot to grow below the first inflorescence in order to have two stems per plant, for a density of 20,200 plants/ha and 40,400 stems/ha. The growth of the tomato plants was allowed until the ninth fruit cluster's emission on the main stem and seventh fruit cluster on the lateral stem, for a total of 16 fruit clusters emitted throughout the life cycle.

The harvest was carried out between 07/21/2019 to $10 / 28 / 2019$, with a total of twelve harvests until the emission of the ninth cluster (C9) of fruits on the main stem (1) and the seventh cluster (C7) of fruits on the lateral stem (2), for a total of 16 fruit clusters emitted in the two stems (1C1, 1C2, 2C3, 1C4..., $2 \mathrm{C} 15,1 \mathrm{C} 16)$ throughout the whole tomato life cycle. In each cluster, the number of fruits was determined for each cluster, and for each fruit, the parameters weight (g), equatorial diameter and longitudinal diameter were determinate. Finally, the number of fruits and fruit yield per cluster for the extra $(>80 \mathrm{~g})$, commercial (50 - $80 \mathrm{~g})$ and non-commercial (<50 g) qualities, and total accumulated yield were estimated as the total accumulated weight of fruits.

One-way analysis of variance (ANOVA) was performed to reveal differences within each treatment (scion/rootstock combinations) for all measured parameters. For the mean comparison, an Honestly Significant Difference-HSD Test was applied, using the $\mathrm{R}$ project "agricolae" package (R Core Team, 2017). For the number of fruits and yield per cluster, a combined analysis by scion $\mathrm{x}$ rootstock combinations was performed. The variables longitudinal and equatorial diameter of tomato fruits and their relationship with weight per fruit were analyzed after regression analysis using Statgraphics (5.1). The dependent variables were $\mathrm{LD}$ and $\mathrm{ED}$ (DV), and the two independent variables were weight and treatment (VI). The procedure consisted of obtaining the least-quadratic equation that best expressed the relationship between the DV and VI and estimated the quality of the regression equation obtained using the coefficient of determination.

\section{RESULTS AND DISCUSSION}

The weight and number of fruits for each harvested order of cluster are presented in figure 3 . The weight per cluster $(P>0.05)$ and the number of fruits for each cluster $(P>0.05)$ were not significantly affected 
by the scion $\mathrm{x}$ rootstock combinations, while the order of emission of the cluster significantly affected the weight and number of fruits. On the other hand, the yield and the number of fruits among the 16 clusters, independent of the grafting treatments, was observed that the weight and number of fruits decrease with the order of emission, being the first clusters (1C1 and 1C2) of higher weight and number of fruits, values that decrease until the eighth cluster (1C8) and from it up to the cluster 1C16, the clusters generally present similar values in the number and weight of the fruits (Fig. 3).

Pogonyi et al. (2005) found that grafting improved yields per cluster (eight clusters) when compared to non-grafted plants because of the production of a higher quantity of fruits and greater weight and that the first clusters produce more significant quantities than the last ones, both in grafted and non-grafted plants.

For the total number of fruits for each tomato quality, significant differences were found between the different scion $\mathrm{x}$ rootstock combinations for the extra quality $(P=0.0216)$. In contrast, for the commercial $(P=0.388)$ and non-commercial qualities $(P=0.989)$, there were no significant differences. The use of a vigor rootstock provided $38 \%$ more fruit of extra quality than the resistance rootstock and $28 \%$ more than self-grafted and non-grafted plants; on the other hand, the resistance rootstock, self-grafted, and nongrafted plants did not differ from each other for the

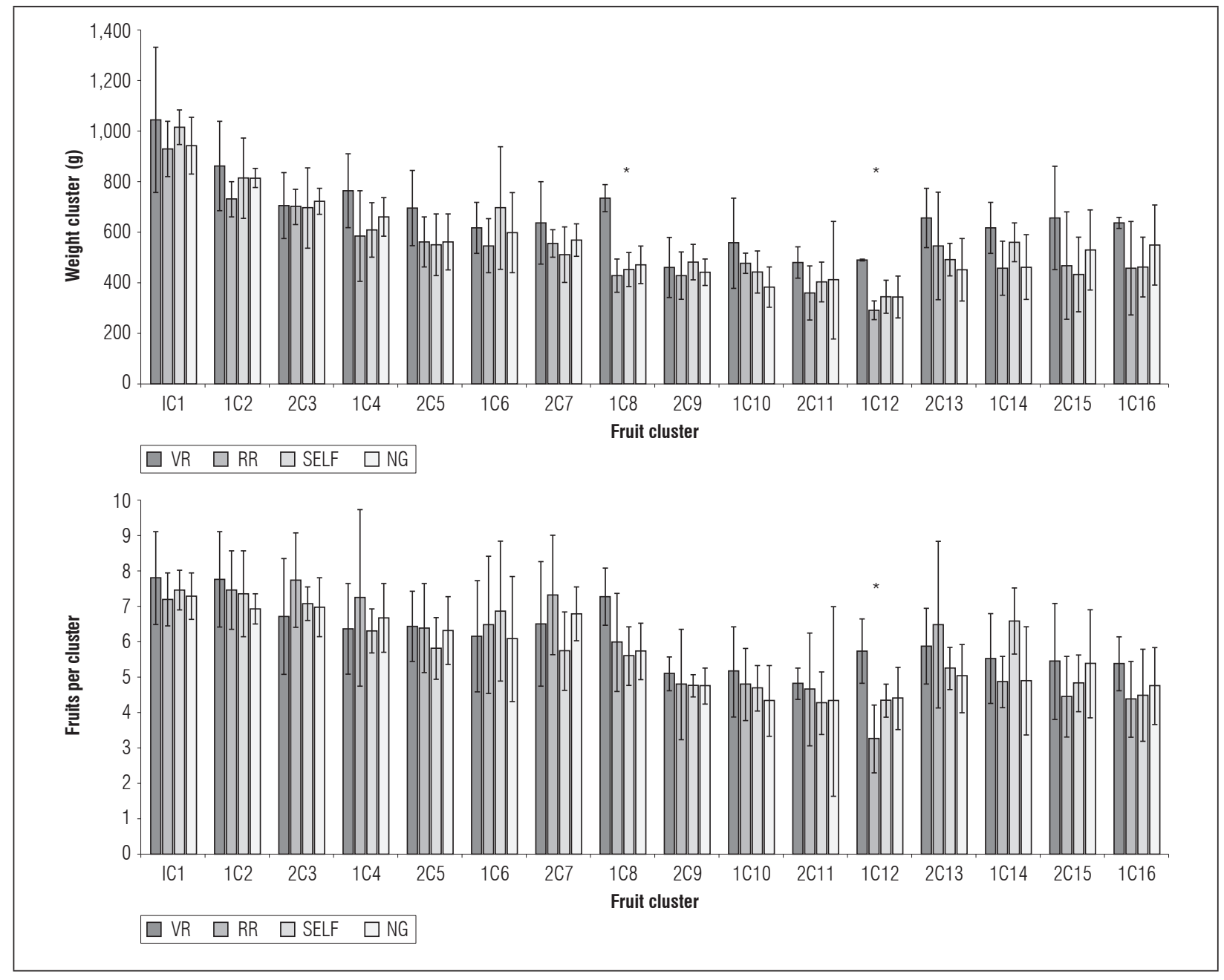

Figure 3. Weight and number of fruits for each tomato cluster for the different scion $\times$ rootstock combinations. Vigor rootstock (VR), resistance rootstock (RR), self-grafting (SELF), and non-grafted plants (NG). Error bars indicate the standard error. * Significant difference at the $5 \%$ level according to Honestly Significant Difference (HSD). 
number of extra quality fruits (Tab. 1). The number of tomato fruits for the extra quality represented $74 \%$ (vigor), $56 \%$ (resistance), $64 \%$ (self-grafted), and $62 \%$ (non-grafted plants) of the total fruits harvested in each treatment. On average, fruits of commercial quality represented $14 \%$ of the total fruits, while the non-commercial quality was $19 \%$ for all treatments (Tab. 1). For the weight per fruit, no differences were observed in each of the fruit qualities nor in the total number of fruits because of different scion $\times$ rootstock combinations (Tab. 1).
For the accumulated yield, the resistance rootstock and the self-grafted and non-grafted plants produced significantly more fresh fruit (first five harvests) than rootstock vigor; however, from the eighth harvest onwards, the rootstock vigor was significant $(P=0.00143)$, exceeding by $21 \%$ the self-grafted and non-grafted plants treatments and having $36 \%$ more than the resistance rootstock (Fig. 4). Other authors observed similar results; the tomato yield under greenhouse conditions was higher in the self-grafted and non-grafted plants; however, in the end, the use

Table 1. The total number and weight of tomato fruits per qualities under different scion $\times$ rootstock combinations.

\begin{tabular}{|c|c|c|c|c|}
\hline \multirow{2}{*}{ Treatment } & \multicolumn{4}{|c|}{ Fruit number per plant } \\
\hline & NC & C & $E$ & Total \\
\hline VR & $9.6 \pm 1.82 \mathrm{a}$ & $16.4 \pm 1.87 \mathrm{a}$ & $72.5 \pm 4.57 \mathrm{a}$ & $98.54 \pm 4.57 \mathrm{a}$ \\
\hline $\mathrm{RR}$ & $19.5 \pm 5.07 \mathrm{a}$ & $21.4 \pm 4.18 \mathrm{a}$ & $52.9 \pm 4.14 b$ & $93.8 \pm 6.10 \mathrm{a}$ \\
\hline SELF & $15.5 \pm 2.37 \mathrm{a}$ & $17.5 \pm 1.76 \mathrm{a}$ & $58.9 \pm 0.92 b$ & $91.3 \pm 3.14 a$ \\
\hline$N G$ & $12.3 \pm 0.93 a$ & $22.1 \pm 0.69 a$ & $56.5 \pm 1.64 b$ & $90.9 \pm 2.93 a$ \\
\hline \multirow{2}{*}{ Treatment } & \multicolumn{3}{|c|}{ Fruit weight by commercial quality (g) } & \multirow{2}{*}{ Mean fruit weight $(g)$} \\
\hline & NC & C & $\mathrm{E}$ & \\
\hline VR & $39.3 \pm 1.60 \mathrm{a}$ & $66.4 \pm 0.94 \mathrm{a}$ & $125.7 \pm 0.92 \mathrm{a}$ & $104.9 \pm 3.69 a$ \\
\hline $\mathrm{RR}$ & $38.5 \pm 0.94 \mathrm{a}$ & $65.4 \pm 1.41 \mathrm{a}$ & $118.9 \pm 3.04 \mathrm{a}$ & $89.3 \pm 4.85 a$ \\
\hline SELF & $37.8 \pm 0.17 \mathrm{a}$ & $64.4 \pm 0.61 \mathrm{a}$ & $121.9 \pm 4.97 \mathrm{a}$ & $97.2 \pm 3.95 \mathrm{a}$ \\
\hline$N G$ & $39.4 \pm 1.09 a$ & $68.3 \pm 3.15 \mathrm{a}$ & $121.4 \pm 1.00 \mathrm{a}$ & $96.0 \pm 2.76 a$ \\
\hline
\end{tabular}

Extra (E), commercial (C), non-commercial (NC), vigor rootstock (VR), resistance rootstock (RR), self-grafting (SELF), and non-grafted plants (NG). Bars indicate the standard error. Means with different letters indicate significant differences according to Honestly Significant Difference $(P<0.05)$.

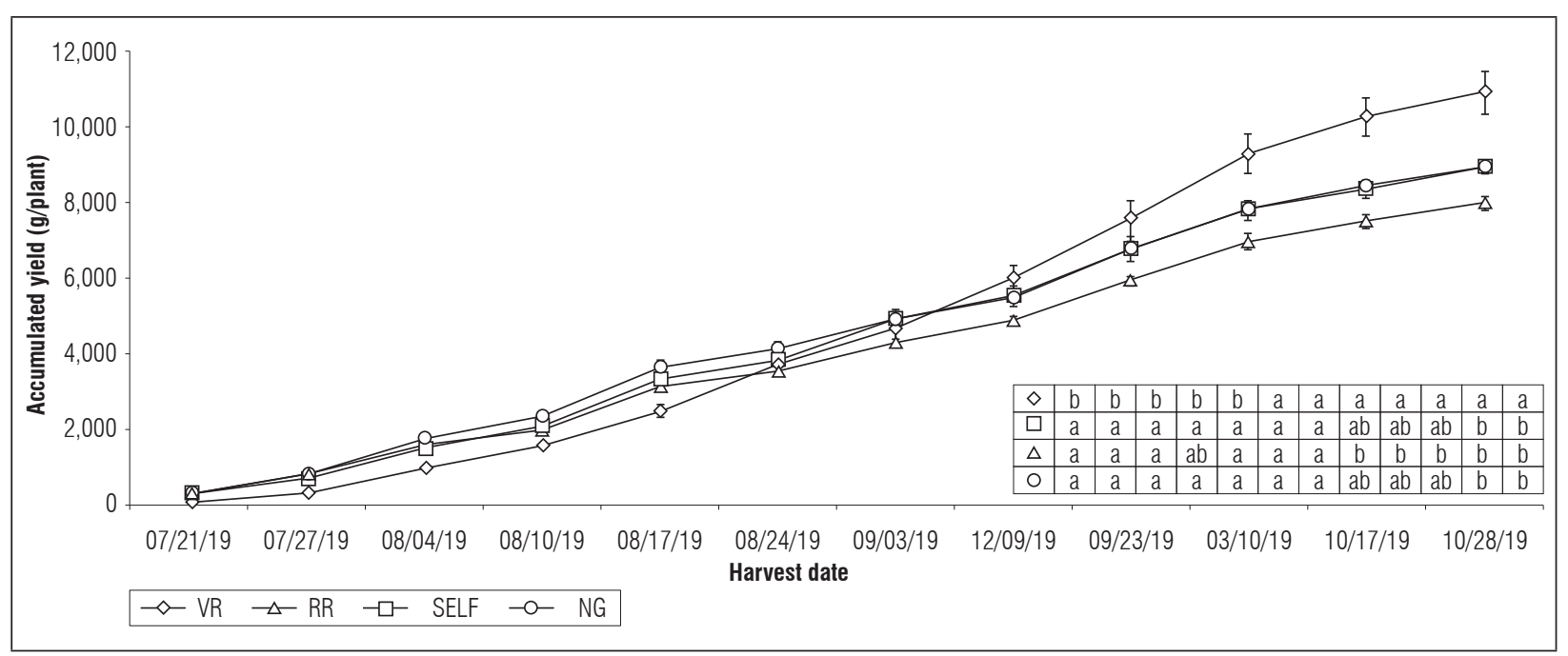

Figure 4. Accumulated tomato fruit yield for the different scion $\times$ rootstock combinations. Vigor rootstock (VR), resistance rootstock (RR), self-grafting (SELF), and non-grafted plants (NG). Harvest was performed between 07/21/2019 and 10/28/2019. Error bars indicate the standard error. Means with different letters indicate significant differences according to Honestly Significant Difference $(P<0.05)$. 
of rootstocks of resistance and vigor significantly exceeded the yields (Pogonyi et al., 2005; Khah et al., 2006). According to Khah et al. (2006), this results because grafted plants present stress from the union of the parts (scion-rootstocks), which delays the maturity of the fruits and their harvest.

The tomato yield varied significantly between the treatments for the extra $(P=0.0000626)$, commercial $(P=0.00011)$ and non-commercial qualities $(P=0.000000948)$; likewise, the total yield per plant and area $(P=0.00118)$ was significantly affected by the different grafting combinations. For contribution to total production, the extra (E) quality fruits represented $86 \%(9.7 \mathrm{~kg} /$ plant $)$ of the yield of plants grafted on rootstock vigor, which was statistically different from $75 \%(6.01 \mathrm{~kg} / \mathrm{plant}), 81 \%(7.4 \mathrm{~kg} /$ plant) and $77 \%(7.1 \mathrm{~kg} /$ plant $)$ of the contribution in resistance rootstock, self-grafted, and non-grafted plant treatments, respectively. The highest weight of commercial-grade (C) fruits was observed in the non-grafted plant treatment $(1.5 \mathrm{~kg} /$ plant $)$, while the highest yield in non-commercial (NC) quality was observed in the resistance rootstock combination (0.73 kg/plant) (Fig. 5).

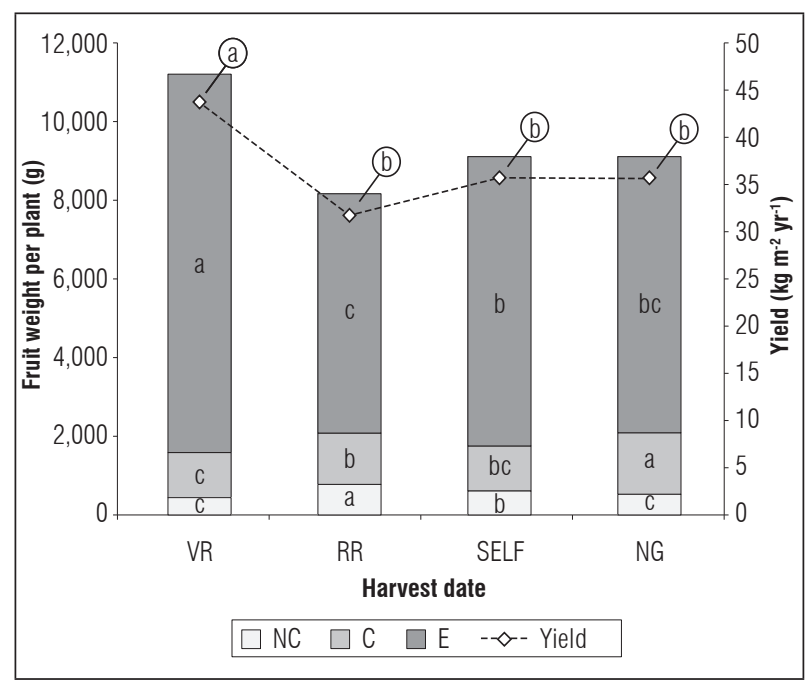

Figure 5. Tomato fruit yield for the scion $\times$ rootstock combinations. Noncommercial (NC), Commercial (C), and Extra (E) fruit quality. Vigor rootstock (VR), resistance rootstock (RR), self-grafting (SELF), and non-grafted plants (NG). The harvest was performed between 07/21/2019 and 10/28/2019. Means with different letters indicate significant differences according to Honestly Significant Difference $(P<0.05)$.
For total yield by area, it was determined that, when the scion was grafted on a vigorous rootstock, the yield was $40 \%$ higher than when it was grafted on a disease-resistant rootstock and 20\% higher than both control treatments (self-grafted and non-grafted plants) (Fig. 5). The difference between the yield for each treatment vigor $\left(43.9 \mathrm{~kg} \mathrm{~m}^{-2}\right)$, resistance $(32.0$ $\mathrm{kg})$ self-grafted $(36.0 \mathrm{~kg})$ and non-grafted $(35.9 \mathrm{~kg})$ plants, was explained by the more significant number of fruits and extra quality yield produced in the vigor treatment, which was 60,30 and $40 \%$ more than the resistance rootstock, self-grafted, and nongrafted plant treatments, respectively (Fig. 5).

A higher yield of tomato plants depends on the proper selection of both the scion and the rootstock (Ntatsi et al., 2014; Hossain et al., 2019). The results in several studies are not precise; some indicate that the use of grafted plants increases yield; however, other authors have reported an adverse effect of grafting on the performance of the commercial scion.

Adverse effects on performance were reported by Hossain et al. (2019) when comparing grafted plants with non-grafted and self-grafted controls; grafting reduced yield by $10 \%$ by area and $15 \%$ by plant. Miskovic et al. (2016), when grafting tomato cultivar 'Jeremy' on eggplant rootstock cv. Madona, observed an adverse effect of the eggplant rootstock by reducing the yield of cv. Jeremy by $43 \%$. Ntatsi et al. (2014), when grafting the commercial cv. Kommeet on the rootstock LA 1777, observed a significant reduction in yield concerning the non-grafted and self-grafted controls. Finally, Riga (2015) evaluated the grafting of a commercial stem on nine different rootstocks and their respective controls (non-grafted and selfgrafted) and, although the yield, number of fruits per area, and average weight of the fruits they did not show statistical differences, observed that the rootstocks tended to be detrimental to the quality parameters.

For positive effects on tomato yield in different scion $\mathrm{x}$ rootstock combinations, different results have been reported. 'Yanki F1' and 'Esin F1' scions grafted onto 11 rootstock combinations showed an increase in yield when compared with self and non-grafted plants, up to $32.73 \%$ (Geboloğlu et al., 2011). Qaryouti et al. (2007) found that the fruit yield increased between 12 and $38 \%$ when grafting the $\mathrm{cv}$. Cecilia on the 'He-Man' and 'Spirit' rootstocks. Djidonou et al. (2016) found a positive effect on the performance of the cultivar 'Florida 47' when it was grafted on the 

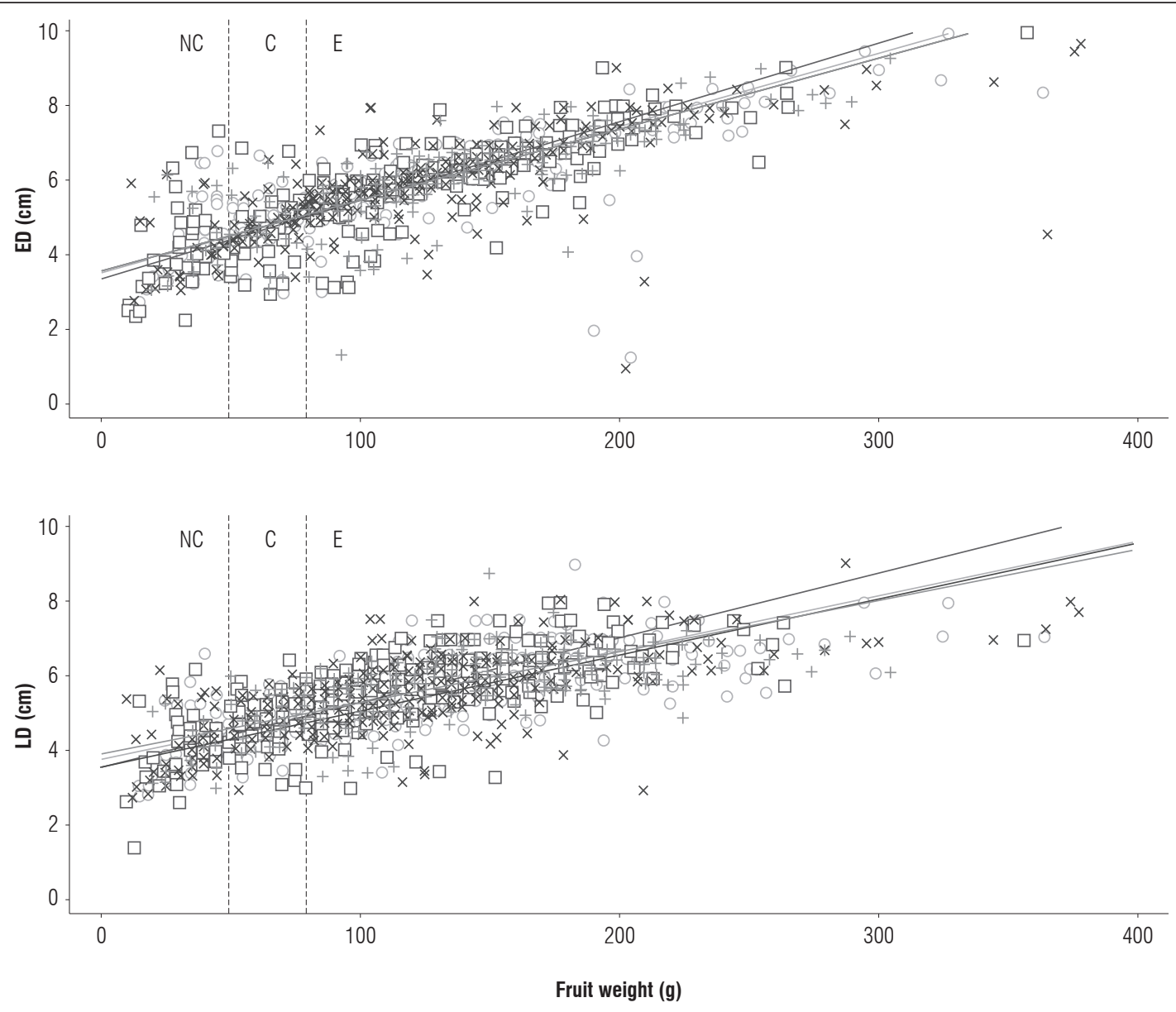

Figure 6. Linear regression models for equatorial diameter (ED) and longitudinal diameter (LD) depending on fruit weight between the different scion $\times$ rootstock combinations. Vigor rootstock (VR), resistance rootstock (RR), self-grafting (SELF), and non-grafted plants (NG).

'Beaufort' or 'Multifort' rootstocks when compared to the non-grafted and self-grafted controls. Hossain et al. (2019), when comparing grafted plants with the self-grafted and non-grafted controls, found that the use of a rootstock improved the yield by area by $50 \%$ and by plant by $56 \%$. According to Rahmatian et al. (2014), the yield per plant increased significantly by $27 \%$ in grafted plants when compared to their selfgrafted and non-grafted plants.

The increase in yield in the grafted plants was due to several factors, including a higher quantity of extra and commercial quality fruits (Qaryouti, et al., 2007; Geboloğlu et al., 2011) and an increase in the total number of fruits (Turhan et al., 2011), in the number of fruits per cluster (Ntatsi et al., 2014), in the weight of fruits (Rahmatian et al., 2014; Djidonou et al., 2016) and the yield per plant (Rahmatian et al., 2014). In addition, the increase in yield in the grafted plants was also attributed to a higher functional relationship between the rootstock and the stem in terms of hormones, proteins and other metabolites (Aloni et al., 2010; Ntatsi et al., 2014), as well as a higher capacity for absorbing water and minerals through a more vigorous root system because of the use of the rootstock (Pogonyi et al., 2005).

The linear regression model was significant $(P=0.0000)$ for the fruit weight as a function of the equatorial and longitudinal diameter, with a significant regression coefficient for the two diameters in all treatments. Figure 6 shows the linear regressions 
of fruit weight as an independent variable, and the respective equatorial diameters (ED) and longitudinal diameters (LD) as weight-dependent variables.

Figure 6 shows that the equatorial and longitudinal diameters reached an approximate value of $6 \mathrm{~cm}$ when the fruits had a weight close to $150 \mathrm{~g}$, indicating that tomato fruits have a circular or round shape. However, an increase in the longitudinal and equatorial diameters was observed for the resistance rootstock treatment at values higher than $150 \mathrm{~g}$, which indicated that the fruits that exceeded this weight tended to have a flatter shape than in the other treatments. In the vigor rootstock, self-grafted, and non-grafted plants, the increase in both diameters was similar, indicating that the fruits tended to have a round shape. When the Yeni Talya, Swanson, and Beril cultivars were grafted on the Beaufort and Arnold standards, the fruits became more flattened with any combination of grafting than in the nongrafted control (Turhan et al., 2011).

\section{CONCLUSION}

The vigorous rootstock increased the tomato yield of the cv. Libertador because of the higher yield and number of extra quality fruits, as compared to the controls self-grafted and non-grafted plants. The scion $\mathrm{x}$ resistance rootstock combination affected tomato yield, as compared to the self-grafted plants. The cv. Libertador fruits grafted on resistance patterns presented a flattened shape after $150 \mathrm{~g}$ of weight, while the shape of the fruit in plants grafted on vigor rootstock, self-grafted and non-grafted plants presented a round shape.

Conflict of interests: The manuscript was prepared and reviewed with the participation of the authors, who declare that there exists no conflict of interest that puts at risk the validity of the presented results.

\section{BIBLIOGRAPHIC REFERENCES}

Aloni, B., R. Cohen, L. Karni, L.H. Aktas, and M. Edelstein. 2010. Hormonal signaling in rootstock-scion interactions. Sci. Hortic. 127, 119-126. Doi: 10.1016/j. scienta.2010.09.003

Bhatt, R.M., K.K. Upreti, M.H. Divya, S. Bhat, C.B. Pavithra, and A.T. Sadashiva. 2015. Interspecific grafting to enhance physiological resilience to flooding stress in tomato (Solanum lycopersicum L.). Sci. Hortic. 182, 8-17. Doi: 10.1016/j.scienta.2014.10.043
Dijonou, D., A.H. Simonne, K.E. Koch, J.K. Brecht, and X. Zhao. 2016. Nutritional quality of field-grown tomato fruit as affected by grafting with interspecific hybrid rootstocks. HortScience 51, 1618-1624. Doi: 10.21273/HORTSCI11275-16

Feller, C., H. Bleiholder, M. Hess, U. Meier, T. Van Den Boom, D.L. Peter, L. Buhr, H. Hack, R. Klose, R. Stauss, E. Weber, and M. Philipp. 1997. Compendium of growth stage identification keys for mono and dicotyledonous plants extended $\mathrm{BBCH}$ scale. $2^{\text {nd }}$ ed. In: https://www.hortiadvice.dk/upl/website/bbch-skala/scaleBBCH.pdf; consulted: March, 2020.

Fullana-Pericàs, M., J. Ponce, M.À. Conesa, A. Juan, M. Ribas-Carbó, and J. Galmés. 2018. Changes in yield, growth and photosynthesis in a drought-adapted Mediterranean tomato landrace (Solanum lycopersicum 'Ramellet') when grafted onto commercial rootstocks and Solanum pimpinellifolium. Sci. Hortic. 233, 70-77. Doi: 10.1016/j.scienta.2018.01.045

Gaion, L.A., L.T. Braz, and R.F. Carvalho. 2018. Grafting in vegetable crops: A great technique for agriculture. Int. J. Veg. Sci. 24, 85-102. Doi: 10.1080/19315260.2017.1357062

Geboloğlu, N., E. Yilmaz, P. Cakm. M. Aydin, and Y. Kasap. 2011. Determining of the yield, quality and nutrient content of tomatoes grafted on different rootstocks in soilless culture. Sci. Res. Essays 6, 2147-2153. Doi: 10.5897/SRE10.1079

Hossain, M.G., M.A. Ali, R.A. Ripa, S. Ayrin, and S. Mahmood. 2019. Influence of rootstocks on yield and quality of summer tomato cv. 'BARI Tomato-4'. Earth Syst. Environ. 3, 289-300. Doi: 10.1007/s41748-019-00101-4

Khah, E.M., E. Kakava, A. Mavromatis, D. Chachalis, and C. Goulas. 2006. Effect of grafting on growth and yield of tomato (Lycopersicon esculentum Mill.) in greenhouse and open-field. J. Appl. Hortic. 8, 3-7. Doi: 10.37855/ jah.2006.v08i01.01

Kumar, P., Y. Rouphael, M. Cardarelli, and G. Colla. 2017. Vegetable grafting as a tool to improve drought resistance and water use efficiency. Front. Plant Sci. 8, 1130. Doi: 10.3389/fpls.2017.01130

Kumar, A.B. and K. Sanket. 2017. Grafting of vegetable crops as a tool to improve yield and tolerance against diseases. A review. Int. J. Agric. Sci. 9, 4050-4056.

Lee, J.M., C. Kubota, S.J. Tsao, Z. Bie, P.H. Echevarria, L. Morra, and M. Oda. 2010. Current status of vegetable grafting: Diffusion, grafting techniques, automation. Sci. Hortic. 127, 93-105. Doi: 10.1016/j. scienta.2010.08.003

Martínez-Andújar, C., J.M. Ruiz-Lozano, I.C. Dodd, A. Albacete, and F. Pérez-Alfocea. 2017. Hormonal and nutritional features in contrasting rootstock-mediated tomato growth under low-phosphorus nutrition. Front. Plant Sci. 8, 13. Doi: 10.3389/fpls.2017.00533 
Milenković, L., J. Mastilović, Ž. Kevrešan, A. Bajić, A. Gledić, L. Stanojević, D. Cvetković, L.J. Šunić, and Z.S. Ilić. 2020. Effect of shading and grafting on yield and quality of tomato. J. Sci. Food Agric. 100, 623-633. Doi: 10.1002/jsfa.10057

Miskovic, A., O. Ilic, J. Bacanovic, V. Vujasinovic, and B. Kukic. 2016. Effect of eggplant rootstock on yield and quality parameters of grafted tomato. Acta Sci. Polon. Hortic. Cul. 15, 149-159.

Muneer, S., H. Ch. Ko, H. Wei, Y. Chen, and B.R. Jeong. 2016. Physiological and proteomic investigations to study the response of tomato graft unions under temperature stress. PLoS ONE, 11, 23. Doi: 10.1371/journal.pone.0157439

Ntatsi, G., D. Savvas, H.P. Kläring, and D. Schwarz. 2014. Growth, yield, and metabolic responses of temperature-stressed tomato to grafting onto rootstocks differing in cold tolerance. J. Am. Soc. Hortic. Sci. 139, 230-243. Doi: 10.21273/JASHS.139.2.230

Pogonyi, A., Z. Pék, L. Helyes, and A. Lugasi. 2005. Effect of grafting on the tomato's yield, quality and main fruit components in spring forcing. Acta Aliment. 34, 453462. Doi: 10.1556/AAlim.34.2005.4.12

Qaryouti, M.M., W. Qawasmi, H. Hamdan, and M. Edwan. 2007. Tomato fruit yield and quality as affected by grafting and growing system. Acta Hortic. 741, 199206. Doi: 10.17660/ActaHortic.2007.741.22

R Core Team. 2017. R: a language and environment for statistical computing. In: Vienna: R Foundation for Statistical Computing, https://cran.r-project.org; consulted: March, 2020.

Rahmatian, A., M. Delshad, and R. Salehi. 2014. Effect of grafting on growth, yield and fruit quality of single and double stemmed tomato plants grown hydroponically. Hortic. Environ. Biotechnol. 55, 115-119. Doi: 10.1007/s13580-014-0167-6
Reddy, P.P. 2016. Grafted vegetables for management of soilborne pathogens. pp. 83-97. In: Reddy, P.P. (ed.). Sustainable crop protection under protected cultivation. Springer, Singapore. Doi: 10.1007/978-981-287-952-3_7

Riga, P. 2015. Effect of rootstock on growth, fruit production and quality of tomato plants grown under low temperature and light conditions. Hortic. Environ. Biotechnol. 56, 626-638. Doi: 10.1007/s13580-015-0042-0

Savvas, D., G.B. Öztekin, M. Tepecik, A.M. Ropokis, Y. Tüzel, G. Ntatsi, and D. Schwarz. 2017. Impact of grafting and rootstock on nutrient-to-water uptake ratios during the first month after planting of hydroponically grown tomato. J. Hortic. Sci. Biotechnol. 92, 294-302. Doi: 10.1080/14620316.2016.1265903

Sen, A., R. Chatterjee, P. Bhaisare, and S. Subba. 2018 Grafting as an alternate tool for biotic and abiotic tolerance with improved growth and production of solanaceous vegetables: Challenges and scopes in India. Int. J. Curr. Microbiol. App. Sci. 7, 121-135. Doi: 10.20546/ijcmas.2018.701.014

Singh, H., P. Kumar, S. Chaudhari, and M. Edelstein. 2017. Tomato grafting: A global perspective. HortScience 52, 1328-1336. Doi: 10.21273/HORTSCI11996-17

Singh, H., P. Kumar, A. Kumar, M.C. Kyriacou, G. Colla, and Y. Rouphael. 2020. Grafting tomato as a tool to improve salt tolerance. Agron. 10, 21. Doi: 10.3390/ agronomy 10020263

Torres, P.A. 2017. Tomate al aire libre. Boletín INIA 376. Instituto de Investigaciones Agropecuarias, Santiago.

Turhan, A., N. Ozmen, M.S. Serbeci, and V. Seniz. 2011. Effects of grafting on different rootstocks on tomato fruit yield and quality. Hortic. Sci. 38, 142-149. Doi: 10.17221/51/2011-HORTSCI 